\title{
Correction to: The Coupling Effect of Flood Discharge and Storm Surge on Extreme Flood Stages: A Case Study in the Pearl River Delta, South China
}

\author{
Xianwei Wang ${ }^{1,2,3} \cdot$ Yu Guo ${ }^{1,2} \cdot J_{i e} \operatorname{Ren}^{3,4}$
}

Published online: 8 November 2021

(C) The Author(s) 2021

\section{Correction to:}

Int J Disaster Risk Sci (2021) 12:495-509

https://doi.org/10.1007/s13753-021-00355-5

The authors' affiliations were missing in the pdf version of this article. The original article has been corrected.

Open Access This article is licensed under a Creative Commons Attribution 4.0 International License, which permits use, sharing,

\begin{abstract}
adaptation, distribution and reproduction in any medium or format, as long as you give appropriate credit to the original author(s) and the source, provide a link to the Creative Commons licence, and indicate if changes were made. The images or other third party material in this article are included in the article's Creative Commons licence, unless indicated otherwise in a credit line to the material. If material is not included in the article's Creative Commons licence and your intended use is not permitted by statutory regulation or exceeds the permitted use, you will need to obtain permission directly from the copyright holder. To view a copy of this licence, visit http://creativecommons. org/licenses/by/4.0/.
\end{abstract}

The original article can be found online at https://doi.org/10.1007/ s13753-021-00355-5.

Xianwei Wang

wangxw8@mail.sysu.edu.cn

1 School of Geography and Planning, Sun Yat-sen University, Guangzhou 510275, China

2 Guangdong Provincial Engineering Research Center for Public Security and Disasters, Guangzhou 510275, China

3 Southern Marine Science and Engineering Guangdong Laboratory (Zhuhai), Zhuhai 519082, China

4 School of Marine Science, Sun Yat-sen University, Zhuhai 519080, China 